\title{
THE DE JURE OBJECTION AGAINST BELIEF IN MIRACLES
}

\author{
GESIEL DA SILVA ${ }^{1,2}$ \\ https://orcid.org/0000-0003-4744-615X \\ ${ }^{1}$ University of Missouri \\ Department of Philosophy \\ U.S.A. \\ 2 State University of Campinas \\ Department of Philosophy \\ Campinas, S.P. \\ Brazil \\ gesiel.gbs@gmail.com
}

Article info

CDD: 200.1

Received: 03.10.2021; Accepted: 04.11.2021

https://doi.org/10.1590/0100-6045.2021.V44N4.GS

\section{Keywords \\ Miracles \\ De Jure objections \\ Epistemic Warrant \\ Religious Epistemology \\ Alvin Plantinga.}

\begin{abstract}
Alvin Plantinga (1993a, 1993b, 2000) argues that de jure objections to theism depend on de facto objections: in order to say that belief in God is not warranted, one should first assume that this belief is false. Assuming Plantinga's epistemology and his de facto/de jure distinction, In this essay, I argue that to show that belief in miracles is not warranted, one must suppose that belief in miracles is always false. Therefore, a person who holds a skeptical position regarding miracles must choose either to find evidence that all of the supposed miracles are false, or admit that one is assuming an areligious commitment as a starting point.
\end{abstract}

Manuscrito - Rev. Int. Fil. Campinas, v. 44, n. 4, pp. 434-452, Oct.-Dec. 2021. 


\section{Introduction: The religious epistemology of Alvin Plantinga and the de facto/de jure dependence}

Among recent contributions to the epistemology of religion, one of the most influential is that of Alvin Plantinga. In the first two volumes of his trilogy, ${ }^{1}$ he discusses and proposes his "normative", general epistemology, and in the last volume, Warranted Christian belief (2000), he applies this "normative" epistemology to religious epistemology in particular. ${ }^{2}$

One of his main goals is to answer objections to the rationality of theism. In order to deal with them, Plantinga (2000, part 2) establishes that there are two sorts of objections against belief in God. The first is what he calls de facto objections, i. e., claims or arguments which aim at showing that belief in God is false. Perhaps the most famous de facto objection to theism is the problem of evil, in either its logical or evidential form. ${ }^{3} \mathrm{D} e$ facto objections are always a matter of truth: the proponent argues that belief in God cannot be considered knowledge because it is false, for God does not exist or his existence is at any rate very improbable. The merits of this objection depend only on questions regarding the truth of theism. ${ }^{4}$

The second kind of objections to theism is what Plantinga calls de jure objections, whose aim is not to show that belief in God is not true (although the objector may think it is false), but to show that it is irrational or defective due to some other reason. There are, of course, many possible $d e$

\footnotetext{
1 Plantinga (1993a, 1993b).

${ }^{2}$ For more on this distinction, see Moon (2016), p. 885-886.

3 See da Silva \& Bertato (2019); da Silva (202

${ }^{4}$ See also Plantinga (2015), p. 7-8, for a shorter explanation of $d e$ facto objections.
} 
jure objections. For instance, one may argue that people believe in God in order to deal with the discomfort of living in a painful world. However, a rational belief should be produced by a reliable truth-aimed mechanism or capacity, not by a comfort-aimed mechanism. Therefore, even if God exists, this belief cannot be rational, for the cognitive mechanism is not aimed at truth, but at psychological comfort instead.

A paradigmatic de jure objection is the one Plantinga labels the "Freud-Marx Complaint". Roughly, like the objection stated above, this objection claims that belief in God is not rational because the cognitive mechanisms that produce this belief suffer from some malfunction. Belief in God is either caused by social dysfunctions (as Marx argued), or by affective necessities that result in wish fulfillment or wishful thinking, projected as belief in God (as Freud defended). In any case, a de jure objection attacks the reliability of the formation of some belief in question. At a first glance, this kind of objection seems to be independent of the truth or falsity of the belief: the problem is that such belief is irrational or defective in some other sense.

Using Plantinga's terminology, we can state the de facto/de jure distinction as follows: while de facto objections claim that belief in God is not true, de jure objections affirm that belief in God is not warranted. ${ }^{5}$ Thus, in the light of this distinction, it seems, in principle, that these objections are completely independent. In fact, the questions they deal with are, in some sense, independent: a belief generally can meet the conditions for warrant and be false; ${ }^{6}$ on the other hand, a

\footnotetext{
5 It is not possible to summarize Plantinga's complete view on rationality and justification. See part I of Plantinga (2000) for further detail, or a shorter exposition in Plantinga (2015, p. 9-25).

6 Plantinga explains the conditions a belief should meet to be warranted: "A belief has warrant for a person $S$ only if that belief
} 
belief can be true but, for some reason, not be warranted for instance, if the person acquires a true belief by luck. We can now apply this to belief in God: one thing is truth, and another, quite distinct, is warrant. For instance, one might say: "I believe in God, but organized religion is a mess; religious leaders use people to get richer, and people that believe in God through these religions are foolish and irrational". But is this distinction sustainable? Is the de jure objection really independent of the de facto question?

According to Plantinga, the answer is no. As he argues in great detail, if belief in God is true, then it is probably warranted: for we can think of a model, a state of affairs that validates such implication. In the model, God created us to know him: we are created with a cognitive mechanism to form belief in God that functions properly, in the appropriate environment, and which aims at true belief in God. ${ }^{7}$ Furthermore, Plantinga argues, a similar situation holds for Christian belief: if Christian belief is true, then it is probably warranted. ${ }^{8}$ On the other hand, if belief in God is false, then it is probably not warranted: as God doesn't exist, probably the mechanisms that form belief in God don't function properly, or don't aim at true belief.

And this leads to a very pertinent result. Many de jure objections rely upon de facto objections: for the adequate formulation of de jure objections must assume that God does not exist in the first place - for, if he exists, belief in God is probably warranted, and the objection fails.

is produced in $S$ by cognitive faculties functioning properly (subject to no dysfunction) in a cognitive environment that is appropriate for S's kind of cognitive faculties, according to a design plan that is successfully aimed at truth.” (2000, p. 153)

7 Plantinga (2000), chapter 6, especially p. 157-158.

8 Op. cit., chapter 8. 
Of course, there are many de jure objections that do not depend on de facto objections. Taking an example from Andrew Moon (2020), if a person forms a belief in God by shaking a Magic- 8 ball, then her belief is vulnerable to a de jure objection, for the belief is not warranted even if God exists. Still, when it comes to belief in God, most de jure claims cannot be made without supposing, explicitly or implicitly, a de facto objection. As Moon explains on the Freudian objection to theism:

"Plantinga responds that if God exists, then theistic belief is not the result of mere wishful thinking. It is ultimately produced by truthaimed, properly functioning, reliable mechanisms designed by God. So, Freud's objection is plausible only on the assumption that God does not exist. Hence, many de jure objections will fail without a successful de facto objection - an argument that God does not exist - which many de jure objectors do not have." (2016, p. 882)

In the following, I assume Plantinga's religious epistemology and his useful de facto/de jure distinction to analyze the case for belief in miracles. Making use of Plantinga's general strategy, I will argue that many objections to belief in miracles are, actually, de jure objections to certain Christian beliefs. I will argue, more exactly, that objections against the reliability of religious testimony (a de jure objection) are dependent on the assumption that belief in miracles is always false (a de facto objection). 


\section{Warrant and belief in miracles}

2.1 Miracles, the Skeptical Position, and a de jure objection against miracles

Now we turn to an analysis of a specific kind of religious belief: belief in miracles. There are many possible positions on what miracles really are when it comes to scientific accounts (for example, concerning laws of nature or scientific explanations), but for the present purposes I'll simply assume that miracles are recognizable deliberate divine interventions. I have two reasons for this position. The first, a more theological reason, is that miracles, in the biblical metanarrative, are always divine interventions in order to accomplish some features of God's plan, either in favour of his people or in favour of some particular person; and these divine actions are always recognizable as signs of his power, wisdom and love. ${ }^{9} \mathrm{~A}$ second reason to assume this minimal definition is that, even if a better definition of miracles is possible, the intension of the concept of "miracle" will generally have "recognizable deliberate divine intervention" among its components, or terms analogous to these; so we can assume that miracles are, at least, recognizable divine interventions with some purpose.

Indeed, this was the original sense of the word miracle: extraordinary events that provoke wonder. As David Corner explains,

\footnotetext{
${ }^{9}$ See, for instance, Acts 2:22 (NVI), in which Peter says that Jesus

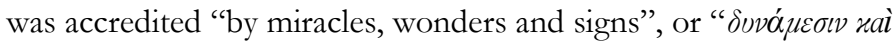

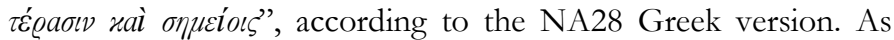
Denis Alexander affirms, these three words in the original are related with the power by which God acts, the recognition by people, and sign of God's operation (Alexander, 2017, p. 3).
} 
"We might observe that the term is from the Latin miraculum, which is derived from mirari, to wonder; thus the most general characterization of a miracle is as an event that provokes wonder. As such, it must be in some way extraordinary, unusual, or contrary to our expectations. Disagreement arises, however, as to what makes a miracle something worth wondering about." (Corner, 2005.)

One of such disagreements is on the nature of miracles. Some argue that miracles necessarily involve violations of the laws of nature. ${ }^{10}$ As Corner affirms, though, both Augustine and Aquinas seem to hold the opinion that "a miracle is not contrary to nature, but only to our knowledge of nature". ${ }^{11}$ This debate is far from being settled. However, since the epistemic status of miracles is the feature that I want to focus on, we can, for the present purposes, be agnostic about their metaphysical structure. ${ }^{12}$ Thus, I assume that miracles are

10 Either because they must be recognized as supernatural interventions or because they are, otherwise, impossible.

${ }^{11}$ Corner, op. cit.

${ }^{12}$ In fact, I'm not sure that miracles are necessarily violations of laws of nature. Even if we assume that all of the miracles (real deliberate divine interventions of some type) cannot be passive of some scientific explanation, it does not mean that they are always violations of laws of nature in the metaphysical sense. Assuming classical theism, as miracles should be recognized by believers and God is infinitely wise, we could think of God as acting sometimes in subtle ways within the laws he established, in order to communicate with his people. But perhaps I'm completely mistaken; be as it is, this footnote does not compromise my argumentation in this paper.

Manuscrito - Rev. Int. Fil. Campinas, v. 44, n. 4, pp. 434-452, Oct.-Dec. 2021. 
recognizable deliberate divine interventions, signs that can be recognized by persons as special divine actions with some purpose. Beginning from this minimal definition, we move now to the case for belief in miracles and warrant.

In the history of philosophy, one of the main critics of the rationality of belief in miracles is David Hume. There is a lot of discussion about his views, and it would be quite impossible to deal with all the literature accumulated around Hume's statements on miracles. However, in one of his famous passages on this topic, Hume remarkably casts doubt on the reliability of testimony for miracles, provided by testimonies; as he says:

"Where shall we find such a number of circumstances, agreeing to the corroboration of one fact? And what have we to oppose to such a cloud of witnesses, but the absolute impossibility or miraculous nature of the events, which they relate? And this surely, in the eyes of all reasonable people, will alone be regarded as a sufficient refutation". (Hume, op.cit., p. 124. $)^{13}$

But how should we interpret such objection? As Denis Alexander points out, Hume seems to think that the forming process of these beliefs is unreliable, due to many possible reasons: "witnesses to alleged miracles are all incompetent, or suffering from delusions, or are not beyond suspicion in some other way, so we cannot really trust them". ${ }^{14}$ John Greco also explains Hume's reasons to doubt testimony:

\footnotetext{
13 The term "cloud of witnesses" is found in the Bible, in Hebrews 12:1 (New International Version).

14 Alexander (2017, p. 3).
} 
Hume believes that the track record that leads testimonial evidence to its source is somehow corrupted. As Greco explains:

"Sometimes people lie, or are self-deceived, or just make a mistake. In any case, the track record is not very good. And in light of that track record, the testimonial evidence for the present case is not very good either. But now all Hume's premises are in place: Our testimonial evidence that an apparent miracle has occurred will never be as good as our evidence that it has not occurred. And this means we can never reasonably believe, on the basis of testimonial evidence, that a miracle really has occurred." (Greco, 2018, p. 91.)

Thus, Hume challenges the reliability of testimony for miracles, making testimony-based belief in miracles unwarranted. Belief in miracles is formed through cognitive mechanisms that are not working properly, and it does not matter whether Hume thinks miracles are possible or not. Also, it does not matter the evidence given by the testimony of people that witnessed some miraculous event; even if in principle what they saw was miraculous, we cannot trust their testimony, and thus, belief in miracles is always not warranted. ${ }^{15}$

15 Some may affirm that there is a third option: Hume has in mind the classical/deontological notion of justification: persons are justified when they accomplish the duty of following the evidence, but the testimonies fail in doing so. However, I argue that even if they are justified in the classical sense (i.e., if they followed the evidence to their best), Hume would still maintain that their 
Such objection to the reliability of testimony can be somehow generalized: the statement that "belief in miracles is always not warranted" can be accepted not only by some humeans, but also by naturalists and other skeptics in general. I call this general thesis the "Skeptical Position" or SP:

(SP) Belief in miracles is necessarily not warranted. ${ }^{16}$

Now, SP can be defended from different personal positions. Let us say that a person, called Skep, is a deist: he thinks that God does not intervene in reality. Another person, Tik, is a naturalist: she thinks there is no supernatural being as God. Skep and Tik have, indeed, very different beliefs about God; however, when it comes to the question of miracles, both agree that miracles are not possible, and both can accept SP consistently, although their arguments for $\mathbf{S P}$ and their degree of acceptance may differ.

Another feature of this claim is that, regardless of arguments to maintain it, $\mathbf{S P}$ is the basis of a de jure objection, and not only to belief in miracles, but also to Christian belief. For Christians believe not only that deliberate divine interventions are possible, but they do believe that, in order to reveal himself, God has performed uncountable miracles throughout history. ${ }^{17}$ Christians believe, above all else, in one

testimony cannot be trusted, and this indicates a de jure objection, according to Plantinga's terminology.

${ }^{16} \mathrm{I}$ recognize that beliefs in miracles come in many kinds. For a while, it is sufficient to see that, according to the definition given in this section, to believe in miracles is simply to believe in deliberate divine interventions.

${ }^{17}$ I will assume, despite criticisms, that there is such a thing as a "normative Christian belief": a minimal commitment to Christian 
miracle: the resurrection of Jesus, the Son of God, the most impressive, improbable, and astonishing miracle that could happen just considering the mere ordinary facts about human nature. If there is just one event we could call miraculous in the biblical metanarrative, this event is the resurrection of Jesus. However, a person who accepts SP has to think, on pain of contradiction, that this Christian belief in Jesus' resurrection is not warranted. Despite the historical evidence for the resurrection of Jesus, Skep and Tik will find some alternative explanation. They could say, for instance, that the apostles were mistaken; that their belief in the resurrection was formed through a mechanism that was not functioning properly, or was not aimed at true belief. In this way, $\mathbf{S P}$ is the central part of a de jure objection to beliefs in miracles, and as miracles are deliberate divine interventions, and Christian belief includes the actuality of such interventions, $\mathbf{S P}$ is the central part of a de jure objection to Christian belief as well.

Now, one more thing should be considered in order to have a precise analysis. There are two contradictory possibilities: either miracles are possible or not. If they are possible, then belief in miracles can be true. If they are not possible, then any belief in miracles is always false. Thus, either belief in miracles can be true, or is always false. Let us analyze in detail these two possibilities regarding warrant.

ecumenical orthodox standards, like belief in the Bible and in its interpretations as expressed the ecumenical creeds - the "catholic faith" common to all of the major traditions in Christianity.

Also, despite historical biblical criticism, most Christians maintain that most miracles in the Bible are real, of even all of them. As I assume Plantinga's epistemology as a background, I suggest the interested reader to see Plantinga (2000), p. 303-341, in which the philosopher deals with potential defeaters that may come from recent Bible scholarship. 


\subsection{Analysing the possibilities}

Inspired by Plantinga's model given in section 1 and by Stephen Wykstra (2002, 2019), let us think about the following state of affairs which validates the proposition "if a Christian belief in miracles is true, then it is probably warranted". In Christian belief, so the model goes, God has created us to know him, so in principle, we are able to have knowledge of God (through sensus divinitatis, or some other natural cognitive mechanism ${ }^{18}$ ). Some of the ways to activate such mechanisms is through miracles; for instance, those found in the Scriptures, and particularly, the miracle of the resurrection of Jesus. When Christians recognize such miracles, they form beliefs through their cognitive apparatus. For instance, they believe in the testimony of the Scriptures and of the Church that Jesus resurrected; ${ }^{19}$ then, Christians think: "Christ died for my sins, and then rose again. That is true". But if this is the case, then a belief in miracles can meet the conditions for warrant, described in section 1 . Therefore, if a Christian belief in miracles is true, then it is probably warranted.

In this model, miracles are actual, so they are at least possible. But many beliefs a Christian may form on supposed miracles can be misguided. A Christian may form her belief in a supposed miracle through arbitrary ways - for instance, she may open YouTube, digit "miracle", watch the first

18 There is a debate on the empirical evidence of such a module as a sensus divinitatis, the faculty responsible for the knowledge of God. Some argue that, even if there is no such module, other faculties, individually or jointly, can function such that knowledge of God may obtain. Moon (2016, p. 883-884) provides an outline of this debate.

19 As Stephen Wykstra holds, testimony reliability is relevant for warranted belief in the resurrection. See Wykstra (2002, 2019).

Manuscrito - Rev. Int. Fil. Campinas, v. 44, n. 4, pp. 434-452, Oct.-Dec. 2021. 
video that appears relating a false miracle, and believe in such a supposed miracle. Even in the case in which the miracle is true, her belief would not be warranted; isn't this a problem? I don't think so. The fact that some beliefs in miracles are false does not mean that Christians are necessarily credulous; moreover, even if some believer is credulous, for instance, believing in miracles like the person who believes in God on the basis of a Magic- 8 ball or by watching a supposed miracle on YouTube, such cases do not touch our subject. For, in this model, if there are actual miracles, this only means that there are actual states of affairs in which God wants to be known. In such cases, he acts through miracles that signalize his specific communication, in such a way that the beliefforming systems of believers are attuned; thus, when believers see those miracles (actual deliberate divine interventions), their beliefs in such miracles are warranted. Therefore, in the given model, if a Christian belief in miracles is true, then it is probably warranted. And if some beliefs in miracles are warranted true beliefs, persons can recognize and know these miracles as deliberate divine interventions.

Let us now consider the other possibility: belief in miracles is false - in this case, necessarily false: there is no such a thing as a miracle. Plantinga has shown that, if the Christian belief in God is false, then it is probably not warranted, and I think that the same reasoning applies to belief in miracles. If all beliefs in miracles are false, we should agree with SP: belief in miracles is not warranted. For instance, in the case of the resurrection, the disciples could have desired to see their Master so heartfully, due to the impact of walking with Jesus for such a long time, and the events that Christians always remember in Maundy Thursdays and Good Fridays were so intense and traumatic, that their cognitive faculties were not functioning properly, or not aiming at true beliefs; for short, their belief in the resurrection was not warranted. And if their belief in the 
resurrection was not warranted, then the same is true of other beliefs Christians hold. ${ }^{20}$

\subsection{De facto and de jure dependence regarding miracles}

But here we reach a relevant point. In the model provided, objections to miracles are objections to Christian belief. As I have said in the first section, Plantinga considers that the de facto objection is not independent of the de jure objection in Freud-Marx's case. There is some dependence between warrant and truth: to say that Christian belief is not warranted, one must suppose (sometimes implicitly) that Christian belief is false. As he says:

"This dependence of the question of warrant or rationality on the truth or falsehood of theism leads to a very interesting conclusion. If the warrant enjoyed by belief in God is related in this way to the truth of that belief, then the question whether theistic belief has warrant is not after all independent of the question whether theistic belief is true. So the de jure question we have finally found is not, after all, really independent of the de facto question; to answer the former we must answer the latter." 21

And here we have a similar situation: to affirm that Christian belief in miracles is necessarily not warranted, one

\footnotetext{
20 As Paul the Apostle says, "if Christ has not been raised, your faith is futile" (1 Corinthians 15:17a, NIV).

21 Plantinga, A. (2015), p. 41 (emphasis in the original).
} 
must suppose that Christian belief in miracles is necessarily not true; thus, belief in miracles is necessarily not warranted if, and only if, belief in miracles is necessarily false. On the one hand, as I said, some beliefs in miracles may still be not warranted; on the other, when it comes to $\mathbf{S P}$, things are different: the $\mathbf{S P}$ claims that belief in miracles is necessarily not warranted. However, SP cannot be supported without supposing, in the first place, that belief in miracles is necessarily false (for if a certain Christian belief in miracles is true, then it is probably warranted). Therefore, a de jure objection concerning miracles that is based on SP is not independent of the de facto objection on the truth of recognizable deliberate divine interventions.

But some might say here: why should we be surprised? Whatever applies to Christian belief, applies to belief in deliberate divine interventions as well. However, our focus here is another: $\mathbf{S P}$, an allegation about the warrant of belief in miracles, puts forward an epistemological question. However, in order to argue successfully for SP, Skep, Tik, or another skeptic, cannot just rely upon epistemological claims: they must go on and embrace a metaphysical or theological assumption. For all that has been argued, it seems that what really grounds a de jure objection or a debunking argument regarding miracles are the metaphysical or theological grounds regarding the possibility of the truth of belief in miracles. In other terms, de jure objections to belief in miracles are not religiously neutral; they are grounded on metaphysical or theological assumptions. ${ }^{22}$

Now, someone that endorses SP may still affirm that miracles are impossible. But to show that they are, I suggest that a SP-defender should choose one of these options:

22 Or, as Plantinga says, "the metaphysical or ultimately religious roots of the question concerning the rationality or warrant or lack thereof for belief in God" (op. cit., p. 40). 
either she assumes her commitment to an atheological or areligious assumption, and this implicitly is also an admission that a Christian belief in miracles can be warranted; or she must appeal to evidences for the assumptions that miracles are impossible. But it seems to be really hard to show that all of the supposed instances of miracles are false, in order to hold that belief in miracles is necessarily not warranted.

From a Christian standpoint, however, things are much less "dramatic". A Christian does not aim at and does not need to believe that every supposed miracle is true, and does not need to be credulous. Belief in recognizable deliberate divine intervention can be properly basic and even warranted for her, and may be accepted regardless of arguments for or against miracles. On the other hand, if an evidentialist challenges her position, it is easier to argue for her position than for a person which holds SP: to show that miracles are possible, only one miracle is needed.

\section{Final remarks}

In this paper, I assumed Plantinga's religious epistemology and the de facto/de jure distinction to argue that, to show that belief in miracles are not warranted, one must suppose in principle that belief in miracles is always false. The Skeptical Position or SP, according to which belief in miracles is not warranted, is committed to the allegation that miracles are impossible, and that is clearly harder than showing that just some beliefs in miracles are not warranted. So, a person who holds SP must choose one of the following strategies: either find evidence that all of the supposed miracles are false, which is quite difficult, or admit one's commitment to an areligious position regarding God. On this framework, a Christian is in a better position when it comes to miracles. 
Of course, this argument holds only if we assume both Plantinga's general and religious epistemology, and if his de facto/de jure distinction also holds. If the argument is sound, however, perhaps the best thing a $\mathbf{S P}$-defender could do is to accept some sort of anti-evidentialist position analogous to that of Plantinga; for if she gives herself the burden of proving that all of the miracles are false, the problem of induction may become a trap, and a miracle with so much historical evidence may be, in this case, the relevant "black swan". ${ }^{23}$

\section{Acknowledgements}

Thanks to Davi Bastos, Fábio Bertato, Marcelo Cabral, Bruno de Souza, and especially Luís Oliveira, for many helpful suggestions on early versions of this paper. I thank also the students and researchers of the Centre for Logic, Epistemology, and the History of Science of the University of Campinas and of the Laboratory on the Epistemology of Religion of the University of Brasilia, where I presented previous versions of this work, for many interesting objections and comments.

This research was made possible through the support of the John Templeton Foundation (Grant IDs 61108 and 61263). The opinions expressed in this paper are those of the author and do not necessarily reflect the views of the John Templeton Foundation.

\footnotetext{
${ }^{23}$ See, for example, Nicholas T. Wright (2003), in which he collects historical evidence for the resurrection of Jesus, and argues that one can just avoid the total evidence by holding a naturalist position. Wright's argument has some resonance with the position defended here. See also Swinburne (2003) for a more philosophical account.
} 


\section{References}

Alexander, D. (2017). Miracles and science. Faraday Papers. Cambridge: The Faraday Institute for Science and Religion.

Corner, D. (2005). Miracles. Internet Encyclopedia of Philosophy (online).

Da Silva, G. B., \& Bertato, F. M. (2019). A first-order modal theodicy: God, evil, and religious determinism. South American Journal of Logic, 5(1), 49-80.

Da Silva, G. B. (2020). An axiomatic approach to theodicy via formal applied systems. Master Thesis in Philosophy, University of Campinas.

Greco, J. (2018) Transmitting faith and garbage. European Journal for Philosophy of Religion, 10 (3), 85-104.

Hume, D. (1748/1975). Enquiries Concerning Human Understanding and Concerning the Principles of Morals. Oxford: Oxford University Press.

McGrew, T. (2019). Miracles. Stanford Encyclopedia of Philosophy (online).

Moon, A. (2016). Recent work in reformed epistemology. Philosophy Compass 2016; 11: 879-891.

Moon, A. (2020). Circular and question-begging responses to religious disagreement and debunking arguments. Philosophical Studies. doi:10.1007/s11098-020-01458-3

Morris, W., \& Brown, C. (2019). David Hume. Stanford Encyclopedia of Philosophy (online).

Novum Testamentum Graece (2012). Nestle-Aland. 28th ed. Stuttgart: Deutsche Bibelgesellschaft. 
Plantinga, A. (1993a). Warrant: The Current Debate, Oxford: Oxford University Press.

Plantinga, A. (1993b). Warrant and proper function. New York: Oxford University Press.

Plantinga, A. (2000). Warranted Christian belief. New York: Oxford University Press.

Plantinga, A. (2015). Knowledge and Christian belief. Grand Rapids: Eerdmans.

Swinburne, R. (2003). The resurrection of God incarnate. Oxford: Oxford University Press.

The Holy Bible, New International Version (1984). Grand Rapids: Zondervan.

Wright, N. T. (2003). The resurrection of the Son of God. Fortress Press.

Wykstra, S. (2002). 'Not done in a corner': how to be a sensible evidentialist about Jesus. Philosophical Books, 2, 92-116.

Wykstra, S. (2019). Warranted Christian resurrection belief: sensible evidentialism, communitarianism, and Plantinga's diffident dilemma, or: a tale of two models. Unpublished; available here.

$(c c) \mathrm{BY}$ 